\title{
Formalising human resource practices in family-owned accommodation Small and Medium-sized Enterprises (SMEs): Integrating owner-manager's personal characteristics with aspects of the UTAUT model
}

\section{Authors:}

Willard Nyamubarwa ${ }^{1}$ (D)

Crispen Chipunza ${ }^{2}$ (D

Affiliations:

${ }^{1}$ Department of Human

Resource Management,

School of Social Sciences,

Great Zimbabwe University,

Masvingo, Zimbabwe

${ }^{2}$ Department of Business

Management, Faculty of

Management Sciences,

Central University of

Technology, Bloemfontein,

South Africa

Corresponding author:

Willard Nyamubarwa,

wnyamubarwa@gzu.ac.zw

Dates:

Received: 03 Mar. 2021

Accepted: 05 May 2021

Published: 26 July 2021

How to cite this article:

Nyamubarwa, W., \& Chipunza,

C. (2021). Formalising human

resource practices in

family-owned accommodation

Small and Medium-sized

Enterprises (SMEs):

Integrating owner-manager's

personal characteristics with

aspects of the UTAUT model.

SA Journal of Human Resource

Management/SA Tydskrif vir

Menslikehulpbronbestuur,

19(0), a1595. https://doi.

org/10.4102/sajhrm.

v19i0.1595

Read online:
Orientation: The decision to formalise human resource (HR) practices by family-owned small and medium-sized enterprises (SME) is regarded as one of the key managerial practices that the owner-manager may institute to unlock firm value. Given this owner manager's overarching role in the decision-making processes, the extent to which his or her personal attributes manifest themselves in deciding to formalise human resource management practices within a specific decision-making model is still a grey area in studies of family businesses.

Research purpose: This study aims to use aspects of the Unified Theory of Acceptance and Use of Technology (UTAUT) model to explain how owner-manager's personal characteristics that influences the decision to formalise HR practices in family-owned SMEs.

Motivations for the study: Previous studies have failed to use recent decision-making models to explain HR formalisation in family businesses and therefore there is dearth of empirical evidence on how owner-managers' personal characteristic influence their decision to formalise HR practices.

Research approach/design and method: Data was collected using convenience sampling method and the data was analysed using Structural Equation Modelling (SEM) to test the veracity of the proposed structural model.

Main findings: The owner-manager's personal attributes have a strong bearing on the decision-making processes in family-owned SMEs.

Practical/managerial implications: The study identifies some personal considerations that are important in the decision to formalise HR practices in family-owned SMEs.

Contribution/value-add: The study contributes to literature on formalising HR practices in family businesses by integrating aspects of an existing decision-making model and demographic characteristics.

Keywords: formalisation; family-owned SMEs; owner-manager; decision-making.

\section{Introduction}

According to the Organisation for Economic Cooperation and Development (OECD) (2017), family-owned small and medium-sized enterprises (SMEs) are increasingly becoming part of the global economy owing to their contributions, to some extent, to employment creation, economic empowerment, wealth redistribution and the overall contribution to Gross Domestic Product (GDP) in many countries across the globe. For example, SME formalisation efforts in Europe have yielded significant returns as the firms now account for $99.8 \%$ of the total number of firms, $66.6 \%$ of total European Union (EU) employment and generating $€ 4030$ billion in 2016, which represents $56.8 \%$ of total exports (PWC, 2018).

However, as Maduku (2015) observed, compared with developed economies, the contribution of family-owned SMEs to GDP figures in emerging economies such as South Africa is grossly understated as a result of, amongst other factors, the informality that characterises their business

Copyright: (C) 2021. The Authors. Licensee: AOSIS. This work is licensed under the Creative Commons Attribution License. 
operations. As a result, some global policymakers such as the International Labour Conference (ILO, 2016) have prescribed formalisation of human resource (HR) practices, such as training and development, as the all-powerful antidote needed to ensure family-owned SMEs effectively contribute to GDP growth in emerging economies.

In fact, the call to formalise HR practices in the SME sector is getting louder daily as more policymakers and governments alike discover the potency of family-owned SMEs in economic development. For example, Yoshino and Taghizadeh-Hesary (2018) reported that in Asia where family-owned SMEs contribute $62 \%$ of all jobs, authorities have recommended HR formalisation as a way of unlocking the sector's contribution to other economic activities, such as job creation. Similarly, in South Africa, OECD (2017) reported that even though familyowned SMEs contribute only $45 \%$ of the total labour force and 33\% of GDP, formalising HR practices might boost their contribution twofold.

Meanwhile, despite the aforementioned virtues of formalising SME operations, previous efforts to formalise HR practices in family-owned business operations have focused mainly on government incentives (Singh \& Vohra, 2009), availability of funding (Harney \& Dundon, 2006) and how large the family is (Steijvers, Lybaert, \& Dekker, 2017) as some of the critical factors. In addition, most of these prominent studies were carried out in Western and Asian economies and only make reference to factors within the operating environment at the expense of personal-driven factors (Psychogios, Szamosi, Prouska, \& Brewster, 2016). As such, the role played by the owner-manager in the day-to-day operations of the family firm and how his or her own characteristics might influence formalistion of business practices within the family business has not been given much attention by family business researchers. As De Massis, Frattini, Majocchi and Piscitello (2018) reported, given the small size and the desire to protect family interests in small family-owned firms, the ownermanager emerges as the sole business-reference person whose personality driven intuition and competency set the business direction for the firm. Steijvers et al. (2017) supported this current postulation by arguing that, in family-owned SMEs, owner-managers bring to the boardroom personalitydriven human capital derived from their skills, experience, age, gender and level of education, which in turn influence the day-to-day management of the firm; in this context, this could mean even the formalisation of HR practices. However, to our knowledge, no study has empirically investigated the extent to which demographic characteristics of owner-managers in family-owned SMEs influence the formalisation of HR practices.

Previous studies on drivers of the decision to formalise HR practices in family-owned SMEs can further be criticised for failing to utilise models that focus on the intra-reasoning of the owner-manager when deciding to formalise family business practices. For example, one study by Mohd Nor (2010) used the Bayesian Causal Map that relies on the power of networking in explaining how even owner-managers who are inexperienced can become experts in making decisions that affect the running of the family business. Recently, renowned family business researchers (Jaskiewicz \& Dyer, 2017) advocated that decision-making in family-owned businesses is best explained by theoretical models that have a wide range of use in a variety of settings, such as the Unified Theory of Acceptance and Use of Technology (UTAUT) (Venkatesh, Morris, Davis, \& Davis, 2003). Originally used in technology adoption, the model argues that the decision to adopt technology is based on the mental reasoning of potential users as one considers issues such as effort expectancy - the belief that adopting a service, technology or strategy will be free of effort or easy and performance expectancy - the belief that adopting a service, technology or strategy will make things better in the firm. Therefore, within the context of this study, it can be argued that whilst the theoretical model has been applied in a variety of settings, its application in understanding the decision to formalise $\mathrm{HR}$ practices by owner-mangers of family-owned SMEs is still void, especially in the context of a gap in literature not showing whether certain personal characteristics have an influence on decision-making related to formalising HR practices. The present study closes these gaps by proposing the integration of some aspects of the UTAUT model, that is, effort expectancy and performance expectancy, with some demographic characteristics of the owner-managers, in order to further contribute to the debate on drivers of formalisation of HR practices in family-owned SMEs.

\section{Research purpose and objectives}

The objective of this study was to determine how selected demographic characteristics of owner-managers of family-owned SMEs interact with aspects of the UTAUT model, effort expectancy and performance expectancy to explain the decision to formalise HR practices in South Africa.

\section{Literature review}

\section{Human resource formalisation in family-owned small and medium-sized enterprises in South Africa}

Meanwhile the South African National Small Business Act of 2004 demarcates small firms into the following distinct categories: micro, very small, small and medium enterprises, with each demarcated category described in terms of the financial performance of the firms and the number of people employed in the firm. Likewise, in defining SMEs, this article embraces all categories of SMEs as stipulated in the National Small Business Act of 2004 to encompass microenterprises with a gross annual turnover of less than R150 000 per annum and employing not more than five people to medium-sized enterprises, which employ up to 200 employees and grossing up to R30 million per annum.

The sector contributes $57 \%$ to the South African GDP and employs $61 \%$ of the total labour force and is viewed by 
policymakers as an agent of transformation playing an increasingly significant role in stimulating economic growth and employment creation for the marginalised black populace (Dzansi \& Tasssin-Njike, 2014; World Bank, 2018).

Despite the contribution of SMEs to economic activity in the country, extant literature reveals that HR practices in SMEs are reactive and informal unlike those from larger companies as HR formalisation is perceived as an unnecessary expense that does not add value to the firm (Li \& Rees, 2020; Steijvers et al., 2017). This is despite the call by policymakers and governments alike for SME formalisation as a panacea to the improvement of the contribution made by SMEs to economic development particularly in emerging economies such as South Africa. For example, the ILO's (2016) recommendation 204, known as the 'Recommendation Concerning the Transition from the Informal to the Formal Economy', calls for the speedy formalisation of the SME sector in all countries through the implementation of formal management systems as a way of promoting efficiency in the informal sector.

When it comes to the practice of HR in South Africa, Nzonzo and Matashu (2014) reported that the informal nature of many SME operations is the major impediment in the proper management of employees in the firm, which in the long run affects the general management of the firms. The same view is echoed by Hung, Cant and Wiid (2016) who reported that HR formalisation is one of the key tools of leveraging the potential of HR in South African SMEs.

\section{The owner-manager's age and effort expectancy}

According to UTAUT, there is a direct relationship between a potential technology user's age and his expectation that the new technology will be easy to use (effort expectancy). Alharbi, Yahya and Ahmed (2018) confirmed this relationship in SMEs when they drew connections between the SME ownermanager's age and his managerial competence and concluded that older SME owner-managers are more likely to adopt formal management practices than their younger counterparts owing to their inherent desire to pursue more long-term goals. The same view is also expressed by Filser, De Massis, Gast, Kraus and Niemand (2017) who reported that the SME owner-manager's age is an important factor in shaping his or her approach towards HR activities in the firm, with older owner-managers being associated with novel HR activities such as HR formalisation. In South Africa, a study by Woldie, Leighton and Adesua (2008) re-affirmed the key role of the owner-manager's age in the proper management of SMEs. In the study, the authors emphasised that the SME owner-manager's age is a key determinant of the busness success of the firm as age-related experience proves to be handy in handiling the flexible and idiosyncratic work environment that charachterise SME operations. In other words, as Elias, Leonard and Mwakujonga (2018) re-affirmed, work competence is accumulated over time and as a result older owner-managers will have had more time to develop and perfect their management skills to effortlessly face any new challenges like HR formalisation. In fact, in line with the relationship between age and effort expectancy in UTAUT, Steijvers et al. (2017) concluded in their study that, in family-owned firms, older owner-managers often perceive a greater need to implement formal HR practices because of their long tenure in managing business-family complexity, which would have opened their eyes to the virtues of formalising HR.

Therefore, driven by the literature reviewed in this section (Filser et al., 2017; Steijvers et al., 2017), this study proposes the following hypothesis:

$\mathrm{H}_{1}$ : There is a positive and significant relationship between the owner-managers' age and effort expectancy.

\section{The owner-manager's level of education and performance expectancy}

According to Svendsen, Johnsen, Almås-Sørensen and Vittersø (2013), a higher level of education enhances the SME owner-manager's capacity for creativity and innovative behaviour within the firm and is likely to appreciate formal methods of business conduct. Karadag (2017) reiterated this assertion and reported that more educated SME ownermanagers are able to manage their firms formally as compared with those who are less educated. In South Africa, Chiliya and Roberts-Lombard (2012) also drew inferences between the owner-manager's level of education and his or her expectation of operating informally and conclude that SME owner-managers with a higher level of education tend to prefer operating formally as compared with those who are less educated. The same view is echoed by Brijlal, Naicker and Peters (2013) who in a study based on South African SMEs also trace a strong rlationship between the level of education and the formal management of the enterprises.

Likewise, in family-owned SMEs, Lobonțiu and Lobonțiu (2014) reported that owner-managers with a higher level of education are more aware of the possible negative repercussions of operating informally and likely to formalise operations. Jiménez, Palmero-Cámara and González-Santos (2015) also shared the same sentiments and noted that the higher the level of education the family-owned SME ownermanager possesses, the greater the possibility that the firm will adopt formal business plans, which often leads to entrepreneurial success and firm growth. Similarly, Steijvers et al. (2017) adopted the same viewpoint and identified tertiary education as the most critical tool an owner-manager of SMEs needs as it provides him or her with the basic expertise needed to run the firm formally.

When it comes to HR in particular, Wilkerson, Seers and Johnson (2020) argued that the more educated the ownermanager is, the more likely the firm is to adopt formal business plans and people management practices. Filser et al. (2017) also traced a relationship between higher educational achievements and formal business practices and reported that the owner-manager's ability to run the HR function professionally is directly tied to his level of education. Although UTAUT does not draw inferences between level of 
education and performance expectancy, some recent studies (Al Mansoori, Sarabdeen, \& Tchantchane, 2018; Garavand, Samadbeik, Nadri, Rahimi, \& Asadi, 2019) have explored this relationsip with success. Therefore, based on these stuies and literature reviewed in this section, this study proposes that the family-owned SME owner-manager's ability to implement formal HR practices is tied to their level of education, with more educated owner-managers associated with higher level of HR formalisation and, therefore, the second hypothesis in this study is proposed as follows:

$\mathrm{H}_{2}$ : There is a positive and significant relationship between the owner-managers' level of education and performance expectancy.

In addition, Jiménez et al. (2015) observed that prior education possessed by an owner-manager lays the proper groundwork for him or her to conduct business formally and with ease. In South Africa, this point is further reinforced by Ogubazghi and Muturi (2014) in their claim that the ease of using new technology depends on the quality of human capital in the form of a set of educational skills possessed by the potential user. In this study, this would imply that, the SME owner-manager's level of education is positively related to the expectation that formal HR practices will be easy to use in the management of employees and hence the following hypothesis was proposed:

$\mathrm{H}_{3}$ : There is a positive and significant relationship between the owner-managers' level of education and effort expectancy.

\section{Performance expectancy of formalising human resource practices}

According to the theory of reasoned action (TRA), a new user's behaviour is based on rationale decision-making with the intention to act in a certain way being a function of the belief that the specific behaviour leads to a given desired outcome (Ajzen \& Fishbein, 1980). This means that a user who perceives that the outcome of performing a certain behaviour is positive will assume a positive attitude towards performing that behaviour and may end up performing that behaviour, with the opposite also true if the behaviour is thought to be negative (Maichum, Parichatnon, \& Peng, 2016). Therefore, it is premised in this study that the decision to formalise HR practices by family-owned SME owner-managers is dependent upon the owner-manger's expectation that using formal HR practices will bring measurable returns, such as decreased costs, increased profits and a wider market share.

The relationship between costs and adoption behaviour can be understood further from the perspective of the transaction cost theory. According to Williamson (2017), a transaction cost is the cost incurred by a firm during the process of participating in any sort of economic exchange. Any competent manager is expected to rationalise the costs of any business transactions they would have engaged in without costly adventures if the tangible benefits are minimal (Erdem \& Atsan, 2015). As a result, the introduction of formal HR practices, as in this study, maybe perceived as a transactional cost that must bring measurable returns if they are to be adopted by the ownermanager. In addition, the family-owned SME ownermanager is expected to weigh the costs of formalising against the potential benefits that will accrue to the firm before making the rationale decision to adopt or reject them.

This is the same approach in UTAUT where Venkatesh et al. (2003) posited a significant relationship between a new system user's performance expectancy and the final decision to adopt or reject a novel system in organisations. This implies, in terms of this study, that the decision to adopt formal HR practices is strongly influenced by the owner-manager's expectation that the formal HR practices will bring measurable and positive returns to their SMEs. In fact, as Ajzen and Fishbein (1980) reported, the potential user's attitude towards adopting a novel practice is based on an assessment of views on both the consequences arising from adopting the new practice and expected contribution of the new practices to the needs of the SME (performance expectancy):

$\mathrm{H}_{4}$ : There is a positive and significant relationship between the owner-managers' performance expectancy and the decision to formalise HR practices in the SME.

\section{Effort expectancy of formalising human resources practices}

The relationship between technology complexity and its potential adoption can also be traced to the innovation diffusion theory (IDT), where Rogers (2003) concluded that the simpler it is to use an innovation, the greater the rate of its adoption by potential users. The same view can also be traced to technology acceptance model (TAM) (perceived ease of use) and UTAUT (effort expectancy), where both theories trace a strong relationship between the ease of using an innovation and the decision to adopt the innovation. Likewise, the UTAUT model which is the basis of this study intimates that the effort expectancy of a potential technology user is directly related to his or her final adoption decision. Therefore, as Garavand et al. (2019) explained, there is a direct relationship between effort expectancy and the use of a new technology. Psychogios et al. (2016) concurred and argued that given the small size of the employee stock in SMEs it follows that the ownermanager has to assume the HR management roles in the firm. However, given the multiplicity of managerial functions, the owner-manager is expected to fulfill, in most instances, the management of HR in family-owned SMEs is done informally as this is amenable with the competence of the owner-manager who in most instances is not an HR expert (Dundon \& Wilkinson, 2018). Basly (2015) admitted to this analysis and reported that in family-owned SMEs, the family may try to keep the HR function under the control of the owner-manager who in most instances will lack expertise in HR management. This state of affairs according to Herrero (2017) may lead to the perception that such formalisation leads to complex managerial practices that may compel the owner-manager to reconsider any formalisation overtures. Instead, as Filser et al. (2017) 
reported, many SME owner-managers prefer a scenario where HR management remains informal and easy to apply as this allows them to juggle the many managerial functions they are expected to fulfil.

In the light of these literature views, the last hypothesis proposed in this study is a follows:

$\mathrm{H}_{5}$ : There is a positive and significant relationship between the owner-manager's effort expectancy and the decision to formalise HR practices in the SME.

The literature reviewed in the preceding sections revealed a number of personal factors that influence the decision by the SME owner-manager to adopt the use of formal HR practices. Therefore, in line with this study's objectives, this literature was used to formulate a structural model (Figure 1) that describes how selected personal factors interact with effort expectancy and performance expectancy to explain the decision to formalise HR practices by owner-managers of family-owned accommodation SMEs in South Africa.

\section{Research methodology Research approach}

The study adopted a quantitative approach to interrogate the hypotheses proposed from a literature review that represent the nature of the relationships between the personal factors that affect HR formalisation in familyowned SMEs in South Africa.

\section{Research participants}

The choice of the small accommodation sector in this study was motivated by the key role played by this sector in the South African tourism landscape. According to Rogerson (2005), this sector wields significant potential in the postapartheid South African economy. The same view is expressed much later by Statistics South Africa (2018), which reported that, in South Africa, the contribution by accommodation SMEs to the GDP increased from $6 \%$ in 2012 to $8 \%$ in 2015, signifying the critical role of these entities in economic development. At the same time, the small accommodation sector generally represents the standard small family-owned firm, which is the focus of this study as most of them are owned and run as family firms usually by a husband and wife team in line with the age-old tradition of offering accommodation to the travelling public (Poza \& Daugherty, 2013). The sector is even more significant in the Free State where the location of the province as a hub between Gauteng, Western Cape, Eastern Cape and KwaZulu-Natal has seen the emergence of many small accommodation firms to tap into the accommodation needs of the travelling public (Strydom, Mangope, \& Henama, 2019).

Meanwhile, the demarcation of family-owned SMEs in this study was based on the definition of family firms from extant literature and the definition of an SME as postulated by the

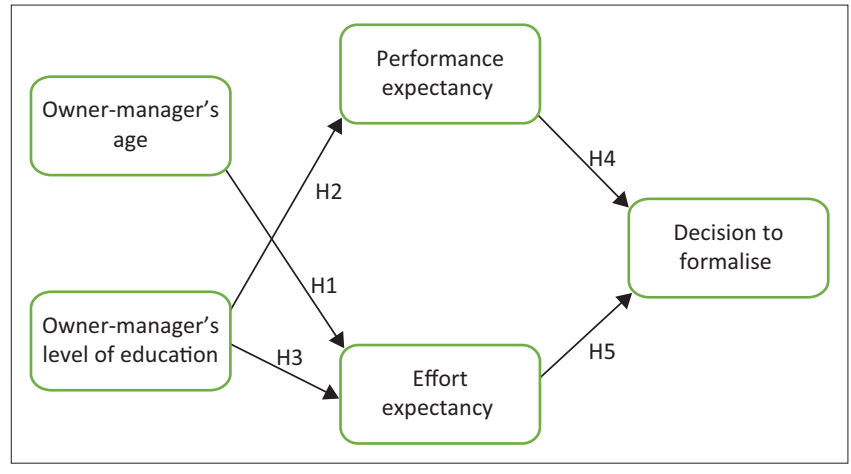

FIGURE 1: The proposed structural model.

National Small Business Act of 2004. Therefore, in this study, a family-owned SME is taken to refer to a firm employing not more than 100 employees and whose practices and policies are controlled by members of the same family. Based on this definition, the target population for this study comprised all family-owned accommodation SMEs in the Free State province, South Africa.

\section{Research procedure}

Based on a database provided by the Free State Tourism Council, at the time the research, there were 431 registered and tax-paying family-owned accommodation SMEs in the province, which constituted the target population of this study. Granted that this study is based on structural equation modelling (SEM), which requires large samples, convenience sampling was used to target a sample of 270 respondents. This figure was deemed adequate by Hair, Black, Babin and Anderson (2014) who reasoned that SEM-based studies based on models with seven constructs or less and modest communalities (0.5) such as this study can produce reliable and valid findings from a sample that is $150<300$.

The researcher therefore engaged and trained research assistants who distributed the research instruments to ownermanagers in family-owned SMEs in the accommodation sector in the Free State province by convenience sampling in order to garner as many respondents as possible.

\section{Measurement model}

Data in this study were gathered using a structured questionnaire. Meanwhile, according to Chumney (2016), in SEM-based studies, the measurement model must be designed in a manner that ensures that the latent variables under review are related to their indicators. As such, in line with this recommendation, this study made effort to carefully design a self-administered structured questionnaire as the study's measurement model.

Consistent with best practices in research of this nature, it is imperative in the design of the measurement model to operationalise the constructs on the measurement model. As such, in this study, the constructs on the measurement model were operationalised by: 
- coming up with a definition of the constructs that are being measured based on extant literature

- selecting items or questions that measured the construct

- selecting the response-format (a five-point Likert scale was used in this study).

\section{Data analysis}

The collected data were integrated in the Analysis of a Moment Structures (AMOS). 24 software package and SEM analysis was used to explore the personal factors affecting the decision to formalise HR practices in familyowned SMEs in South Africa.

Structural equation modelling is a multivariate statistical framework that is used to analyse structural relationships between directly and indirectly observed (latent) variables (Sideridis, Simos, Papanicolaou, \& Fletcher, 2014). In other words, SEM analyses data by estimating the relationships amongst a set of constructs represented by a number of variables making up an integrated testable model (Figure 1).

\section{Research findings Measurement model fit}

As SEM generally comprises two types of models, which must fit the data, the measurement model and the structural model, in data analysis, it is imperative to ensure that the measurement model provides an accurate empirical representation of the underlying hypothetical constructs in the research context (Kelloway, 2015). It is therefore critical to ascertain how well the observed indicators from collected data accurately serve as measurement indicators for the latent variables in the study's context (model fit).

Therefore, in this study, the successful operationalisation of the measurement model was a precondition that had to be met before considering fitting the structural model to the collected data as recommended by Hayes (2017). To facilitate this operationalisation, confirmatory factor analysis (CFA) was used to assess the extent to which the measurement model fitted into the collected data. The CFA results initially displayed unsatisfactory fit indices. However, further diagnosis of the modification indices and the standardised residual covariance matrix retrieved from AMOS.24 necessitated deleting some items from the measurement instrument to improve the instrument's model fit. The modification indices option on AMOS.24 was also used to detect and delete the inter-item correlations affecting the measurement model's fit. As such, the construct decision to formalise retained two out of the original six items. Likewise, the performance expectancy construct retained 2 out of the original 12 items and with the effort expectancy construct, 5 out of a possible 11 items were retained. These retained items converged significantly on their respective constructs as they all recorded factor loadings above $>0.5$ at significant level 0.01 as recommended by Hair et al. (2014). Therefore, the final model indicated satisfactory fit indices after refinement of the measurement model $\left(\chi^{2}=283.395, p=000\right.$,
DF = 124), indicating that the final measurement model fitted satisfactorily with the collected data.

\section{Validity and reliability assessment}

The measurement model was also tested for convergent validity using factor loadings on AMOS.24. The results indicated that the factor loadings of all constructs on the measurement model were all above the recommended threshold of 0.5 as recommended by Field (2013), who showed that all the items on the measurement model were valid to gather data in this study.

The study also assessed the discriminant validity by comparing the square root of the average variance extracted (AVE) with the respective correlation coefficients of the measurement instrument's constructs. There was no discriminant validity concern in the measurement instrument as all correlation coefficients were lower than the square root of AVEs of their respective constructs. This confirmation of the measurement instrument's validity indicates that the relationships illustrated in the measurement model fit the data satisfactorily and, on that basis, the measurement instrument was deemed valid in the context of this study.

\section{Reliability test}

The study also sought to establish the reliability of the measurement model using the Cronbach's alpha coefficient. The results from the Cronbach's alpha test indicate that all the constructs on the measurement model achieved a satisfactory level of reliability as their values were above 0.5 as recommended by Hair et al. (2014).

Based on the results of the CFA and the validity and reliability tests carried out on the measurement model, it is evident that all the relationships illustrated in the measurement model fit the collected data satisfactorily. The final measurement model is shown in Figure 2.

\section{Structural model fit}

The proposed structural model (Figure 1) was tested for data fit using the maximum likelihood estimation (MLE) method against the common fit indices prescribed by Hair et al. (2014). The final structural model $\left(\chi^{2}=1036.350 ; p=000\right.$; $\mathrm{DF}=543)$ displayed a satisfactory fit, which is a clear indication that the study's structural model (Figure 3) fits the collected data satisfactorily and could be used with confidence to test the hypotheses proposed in this study.

This close fit between the structural model and the data collected from the field indicates that the null hypotheses $\left(\mathrm{H}_{0}\right)$ in this study was not rejected and that all the path coefficients of the hypothesised relationships were statistically significant. As such at this stage, the next procedure in SEM analysis involved testing the hypotheses proposed in this study. 


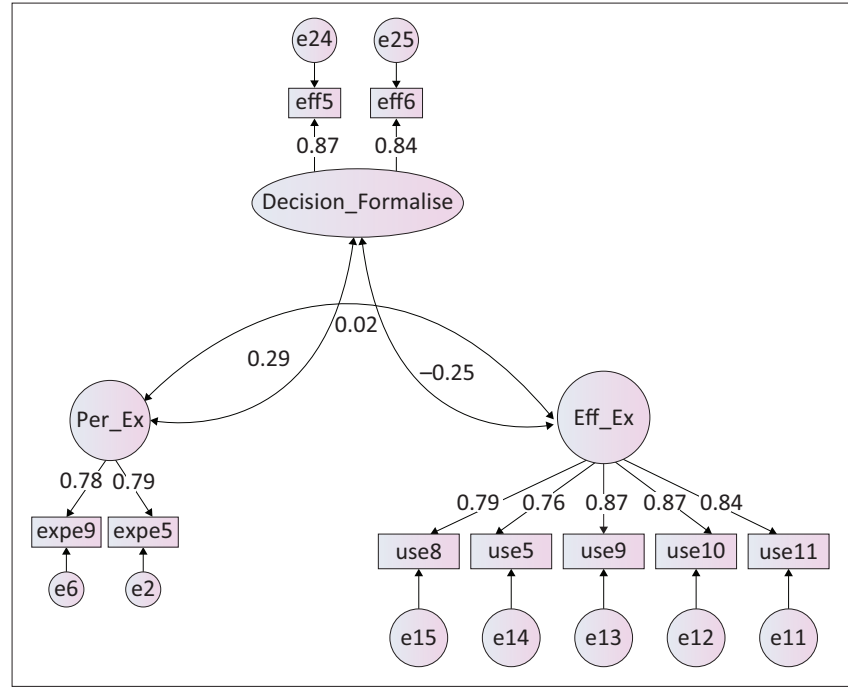

Per_Ex, performance expectancy; Eff_Ex, effort expectancy.

FIGURE 2: Final measurement model.

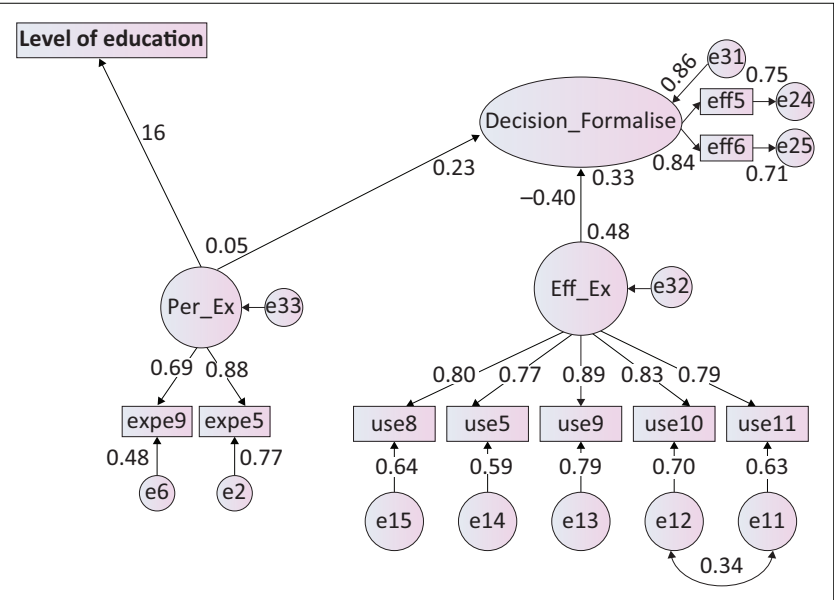

Per_Ex, performance expectancy; Eff_Ex, effort expectancy.

FIGURE 3: Final structural model.

\section{The owner-manager's age and effort expectancy of human resource formalisation}

The relationship between owner-manager's age and the effort expectancy of using formal HR practices was captured in the following hypothesis:

$\mathrm{H}_{1}$ : There is a positive and significant relationship between the owner-managers' age and effort expectancy.

This hypothesis was derived on the basis of the UTAUT model and extant literature (Alharbi et al., 2018; Filser et al., 2017), which indicates that there is a strong relationship between the SME owner-manager's age and the expectation that formal HR practices will be easy to use (effort expectancy). However, empirical findings in this study (estimate: -0.034 ; $p$-value: 0.44$)$ indicate that there is no relationship between the family-owned SME owner-manager's age and effort expectancy of using formal HR practices. The no relationship observation renders the hypothesised relationship rejected and hence on that basis, this study concludes that the ownermanager's age does not influence expectations that formal
TABLE 1: Level of education and performance expectancy.

\begin{tabular}{lllll}
\hline Dependent variable $\quad$ Effect on & Independent variable & Estimate $P$-value
\end{tabular}

\begin{tabular}{lllll}
\hline Performance expectancy & $<---$ & Level of Education & 0.157 & 0.01 \\
\hline
\end{tabular}

HR practices will be easy to use in the family-owned SMEs. Viewed from another angle, this finding validates one of UTAUT's assumptions which claims that effort expectancy is personality driven and as such varies from one person to another and from one context to another; as such in the context of the socio-economic environment in South Africa at the point of collecting data, the difficulty associated with HR formalisation may have been insignificant in influencing the adoption decision.

\section{Owner-manager's level of education and performance expectancy}

In testing the relationship between the family-owned SME owner-manager's level of education and the performance expectancy of using formal HR practices, the following hypothesis was proposed:

$\mathrm{H}_{2}$ : There is a positive and significant relationship between the owner-managers' level of education and performance expectancy.

As Table 1 indicates, the owner-manager's level of education had a positive and significant effect on their performance expectancy of using formal HR practices as its $p$-value (0.01) is lower than 0.05. This means that there was a strong and significant relationship between the SME owner-manager's level of education and his or her expectation that formal HR practices will lead to enhanced firm performance (performance expectancy).

This finding dovetails with the claim made by Venkatesh et al. (2003) who originally proposed the positive relationship between education level and performance expectancy as captured in the UTAUT model. Thus, the current finding validates the relationship proposed in the main theory, UTAUT, anchoring this study. This finding is also in congruence with a study by Al-Khowaiter, Dwivedi and Williams (2014) who found a relationship between the family-owned SME owner-manager's level of education and their attitude towards adopting human resource information systems (HRIS) in Saudi Arabia.

This study's findings reaffirm conclusions drawn by Radipere and Dhliwayo (2014) in an almost similar study based in South Africa, which concluded that owner-managers' educational achievement has a major impact on SME growth as more educated SME owner-managers have the necessary confidence (performance expectancy) needed to foster firms' success. The same conclusion is also made by other scholars researching in South Africa as in this study who also concluded that in South African SMEs, the owner-manager's educational level plays a key role as it arms the ownermanager with greater capacity to learn novel operating practices, such as the use of formal HR practices and the ability to adjust firm's practices to the ever-changing 
operating environment that characterise developing emerging economies such as South Africa (Brijlal et al., 2013; Steenkamp \& Bhorat, 2016).

Therefore, on the basis of these research findings, this study concludes that the owner-manager's level of education influences his or her expectations that formal HR practices will be useful if adopted in family-owned SMEs.

\section{Owner-manager's level of education and effort expectancy}

Regarding the relationship between the owner-manager's level of education and his or her effort expectancy of using formal HR practices, this study formulated the following hypotheses:

$\mathrm{H}_{3}$ : There is a positive and significant relationship between the owner-managers' level of education and effort expectancy.

This hypothesis was based on extant literature (Ogubazghi \& Muturi, 2014; Riddell \& Song, 2017) that indicates that there is a relationship between owner-managers' level of education and their ability to use new products with ease (effort expectancy). However, findings from the current study (estimate: -0.022 ; $p$-value: 0.531 ) refute this and, therefore, the hypothesis was rejected and therefore on that basis this study draws the conclusion that the owner-manager's educational level is not a predictor of the ease of using formal HR practices in family-owned SMEs.

Although the finding of this research runs counter to extant literature, it raises a significant milestone in UTAUT research as it indicates a new trajectory worth pursing away from the well-beaten path reflected in the literature.

\section{Performance expectancy and decision to formalise human resource practices}

Performance expectancy, which refers (in this study) to the owner-manager's expectation that formal HR practices will be useful in the firm, is assumed to be related to the ownermanager's decision to formalise HR practices in family-owned SMEs. In the light of this, the following hypothesis was proposed:

$\mathrm{H}_{4}$ : There is a positive and significant relationship between the owner-managers' performance expectancy and the decision to formalise HR practices in the SME.

As shown in Table 2, the results reveal that performance expectancy has a positive and significant effect on the ownermanager's decision to formalise HR practices because its $p$-value (0.008) is lower than 0.05. This signifies that when performance expectancy goes up by one standard deviation, the decision to formalise also goes up by 0.234 of its own standard deviation.

The findings presented in Table 2 are significant as they tally with the assumptions in the main theory guiding this study, UTAUT. In fact, as Venkatesh et al. (2003) observed in
TABLE 2: Performance expectancy and decision to formalise human resource practices.

Dependent variable Effect on Independent variable $\quad$ Estimate $P$-value
\begin{tabular}{llll}
\hline Decision to formalise $<---$ & Performance expectancy & 0.234 & 0.008
\end{tabular}

UTAUT, a new system user's performance expectancy is a strong predictor of the user's final decision to adopt or reject a novel system in organisations. Therefore, as confirmed by this study, the adoption of formal HR practices is strongly influenced by the owner-manager's perceptions that the formal HR practices will lead to measurable positive returns for the SMEs.

This finding is also in sync with the principles of the TRA which is based on the premise that a new user's behaviour is based on rational decision-making and that the intention to act in a certain way is a function of the belief that the specific behaviour will lead to a given desired outcome (Ajzen \& Fishbein, 1980). This means that a user who perceives the outcome of performing a certain behaviour as positive would have a positive attitude towards performing that behaviour and may end up performing that behaviour whilst the opposite can also be said if the behaviour is thought to be negative (Maichum et al., 2016).

Therefore, in line with the findings of this study, the decision to formalise HR practices by family-owned SME ownermanagers is dependent on the performance expectancy of using formal HR practices in the firms and as such we draw the conclusion that the owner-manager's expectation that formal HR practices will be useful to adopt in the firm influences the decision to formalise HR practices.

\section{Effort expectancy and the decision to formalise human resource practices}

In pursuit of the relationship between the SME ownermanager's effort expectancy and the decision to formalise HR practices in family-owned SMEs, the following hypothesis was proposed:

$\mathrm{H}_{5}$ : There is a positive and significant relationship between the owner-manager's effort expectancy and the decision to formalise HR practices in the SME.

The results from the regression analysis of this hypothesis are presented in Table 3 .

Table 3 shows that there is a negative relationship between effort expectancy of using formal HR practices and the decision to formalise HR practices in family-owned SMEs in South Africa. The $p$-value (0.01) is lower than 0.05 . This means that, as effort expectancy goes up by one standard deviation, the owner-manager's decision to formalise goes down by 0.399 of its own standard deviation.

The above-mentioned findings are at variance with one of the adoption theories, the TAM and UTAUT supporting this study, which trace a positive relationship between effort 
TABLE 3: Effort expectancy and decision to formalise human resource practices. \begin{tabular}{lllll}
\hline Dependent variable & Effect on & Independent variable & Estimate & $\boldsymbol{P}$-value
\end{tabular} \begin{tabular}{lllll}
\hline Decision to formalise $\quad<---$ & Effort expectancy & -0.399 & 0.01 \\
\hline
\end{tabular}

expectancy of using novel technologies and the user's decision to adopt those (Venkatesh et al., 2012). The variance with the findings of this study shows that TAM suggests that people who feel at ease with the complexity of a new invention end up using the invention to a larger extent than those who feel intimidated by the complexity of the invention (Svendsen et al., 2013). Therefore, the TAM posits a link between attitude and the decision to adopt this causal chain implies that a more positive attitude towards the system creates a stronger behavioural intention towards using the system, which ultimately influences the decision to adopt innovations (Kashi \& Zheng, 2013; Svendsen et al., 2013). This is a complete opposite to what the current result entails.

Although this study seems to question the validity of the long-held relationships between TAM and UTAUT, it concludes that the owner-manager's expectation that formal HR practices will be easy to use does not influence the decision to formalise HR practices. Despite this conclusion, HR practitioners must not dismiss the significance of effort expectancy in HR formalisation as it may be a 'hygiene factor', that is, a factor that does not in itself motivate, but leads to demotivation if it is absent.

\section{Practical implications}

The findings of this study may be used to address potential management practices and serve as a guide to the formalisation of HR in SMEs by SME owner-managers, policymakers and HR practitioners in South Africa and beyond. The study revealed that the decision to formalise HR practices is driven by a number of owner-manager-driven personal factors and reaffirms the pivotal role of the ownermanager's personality in the decision-making processes in family-owned accommodation SMEs.

\section{Limitations and recommendations}

A major limitation of this study relates to the time and financial constraints faced by one of the researchers. As a full-time employee residing outside South Africa, the researcher faced severe time and financial constraints regarding balancing between conducting the study and cross-border work commitments.

Another limitation of this study is the confinement of the respondents to the Free State province in South Africa. This may affect the generalisation of the findings to the rest of South Africa or worse still to all emerging economies in general. However, the researcher is convinced that the depth of this study produced credible results that can be applied and retested in other emerging countries and will produce similar results.
It is recommended that that policymakers and $\mathrm{HR}$ practitioners must design a set of HR practices that are easy to understand and use in SMEs as complex HR practices designed for use in large firms can tamper the formalisation of HR practices in family-owned accommodation SMEs.

Lastly, the drivers of HR formalisation examined in this study are not exhaustive. Therefore, future researchers are challenged to consider other factors that may have a bearing on HR formalisation in SMEs. Furthermore, this study was quantitative in nature and, as such, future researchers may want to pursue a qualitative trajectory and use the subjective experiences of owner-managers to further this study's findings.

\section{Contribution of the study}

This study answered the call for research that explores how the unique personality of the owner-manager influences management practices in family-owned SMEs by proposing and testing an integrated structural model that describes how selected personal factors interact with aspects of the UTAUT model, such as effort expectancy, performance expectancy and facilitating conditions, to explain the decision formalises HR practices by owner-managers of family-owned accommodation SMEs in the Free State province of South Africa. The uniqueness of the study, therefore, lies in combining aspects of an existing model and existing empirical evidence to explain the decision to formalise HR practices in family-owned accommodation SMEs in an emerging economy such as South Africa. This study further contributes to the body of knowledge by empirically testing the proposed integrated structural model and coming up with a customised model on how selected personal factors interact with effort expectancy, performance expectancy and facilitating conditions to influence the decision to formalise HR practices by familyowned accommodation SMEs within the South African context.

By developing an integrated model and testing its explanatory power amongst family-owned accommodation SMEs in South Africa, the study represents an empirical step towards addressing the gap in explaining personal factors that can account for the decision to formalise HR practices amongst family-owned accommodation SMEs. The study does so by delineating the critical determinants of the decision to formalise HR practices amongst family-owned SMEs within a specific context in South Africa (Figure 3), which can be used on similar economies.

Figure 4 depicts the personal determinants of HR formalisation amongst family-owned accommodation SMEs in the Free State province of South Africa. The figure shows that the decision to formalise HR practices is influenced by the owner-manager's performance expectancy and effort expectancy. In turn, performance expectancy is influenced by the ownermanager's level of education. 


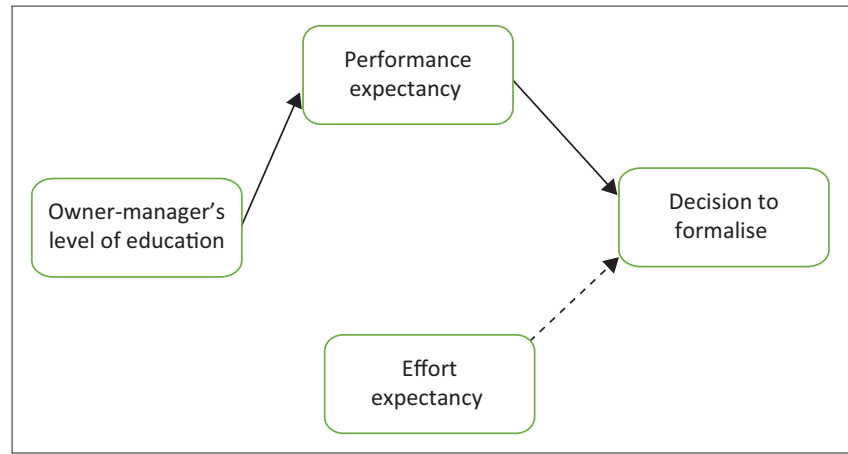

FIGURE 4: Personal factors affecting human resource formalisation in family-owned accommodation small and medium-sized enterprises.

\section{Acknowledgements Competing interests}

The authors declare that they have no financial or personal relationships that may have inappropriately influenced them in writing this article.

\section{Authors' contributions}

In this study, W.N. formulated the problem, collected the data and reviewed literature. C.C. did data analysis and discussion and also did proofreading of the manuscript.

\section{Ethical considerations}

Ethical clearance to conduct the study was sought from and granted by the sponsoring university, Central University of Technology, Free State, with clearance number FMS2014/07.

\section{Funding information}

This study was funded by the Central University of Technology, Free State.

\section{Data availability}

Data can be obtained from the corresponding author (W.N.) upon reasonable request.

\section{Disclaimer}

The views and opinions expressed in this article are those of the authors and not in any way an official position of the funding institution.

\section{References}

Ajzen, I., \& Fishbein, M. (1980). Understanding attitudes and predicting social behaviour. Englewood Cliffs, NJ: Prentice-Hall.

Alharbi, R.K., Yahya, S.B., \& Ahmed, E. (2018). Characteristics of manager's and SMEs performance: The role of access to finance as a moderator. International Journal of Engineering \& Technology, 7(4), 5115-5119. https://doi.org/10.14419/ijet.v7i4.25620

Al-Khowaiter, W., Dwivedi, Y., \& Williams, M. (2014). Examining the adoption of human resource information system in Saudi Arabia. In London, UK Academy for information systems conference proceedings (p. 9).

Al Mansoori, K., Sarabdeen, J., \& Tchantchane, A. (2018). Investigating Emirati citizen's adoption of e-government services in Abu Dhabi using modified UTAUT model. Information Technology and People, 31(2), 455-481. https://doi.org/10.1108/itp12-2016-0290
Basly, S. (2015). Family involvement in the firm and exports in the family SME: Is the manager's International orientation influential. Journal of Intercultural Management, 7(3), 66-69. https://doi.org/10.1515/joim-2015-0022

Brijlal, P.V., Naicker, V., \& Peters, R. (2013). Education and SMME business growth: A gender perspective from South Africa. International Business \& Economics Research Journal, 12(8), 855-873. https://doi.org/10.19030/iber.v12i8.7983

Chiliya, N., \& Roberts-Lombard, M. (2012). Impact of level of education and experience on profitability of small grocery shops in South Africa. International Journal of Business Management and Economic Research, 3(1), 462-470. https://doi. org/10.20460/JGSM.2008218487

Chumney, F. (2016). Structural equation models with small samples: A comparative study of 4 approaches. PhD Thesis. The Graduate College at the University of Nebraska. Lincoln, Nebraska: University of Nebraska.

De Massis, A., Frattini, F., Majocchi, A., \& Piscitello, L. (2018). Family firms in the global economy: Toward a deeper understanding of Internationalization determinants, processes, and outcomes. Global Strategy Journal, 8(1), 3-21. https://doi. org/10.1002/gsj.1199

Dundon, T., \& Wilkinson, A. (2018). HRM in Small and Medium-Sized Enterprises (SMEs). In D.G. Collings, G.T. Wood, \& L.T. Szamosi (Eds.), Human Resource Management: In D.G. Collings, G.T. Wood, \& L.T. Szamosi (Eds.), Human Resource Mantion
A Critical Introduction (pp. 130-149). Abingdon-on-Thames: Routledge.

Dzansi, D.Y., \& Tasssin-Njike, R. (2014). Understanding the transition from informal to formal business: A conceptual framework. Mediterranean Journal of Social Sciences, 5(20), 664-670. https://doi.org/10.5901/mjss.2014.v5n20p664

Elias, R., Leonard, W., \& Mwakujonga, J. (2018). Determinants of owner-manager competencies for small business operations: Evidence from a small restaurant business in Tanzania. Asian Business Research Journal, 3, 41-47. https://doi. org/10.20448/journal.518.2018.31.41.47

Erdem, F., \& Atsan, N. (2015). Trust based relationships between family members and long-term employees of family-owned SMEs. International Business Research, 8(4), 223-232. https://doi.org/10.5539/ibr.v8n4p233

Field, A. (2013). Discovering statistics using IBM SPSS statistics: And sex and drugs and rock ' $n$ ' roll (4th edn.). Los Angeles, CA: Sage.

Filser, M., De Massis, A., Gast, J., Kraus, S., \& Niemand, T. (2017). Tracing the roots of innovativeness in family SMEs: The effect of family functionality and socioemotional wealth. Journal of Production, Innovation and Management, 35(4), 609-628. https://doi.org/10.1111/jpim.12433

Garavand, A., Samadbeik, M., Nadri, H., Rahii, B., \& Said, H. (2019). Effective factors in the adoption of mobile health applications between medical sciences students using UTAUT model. Methods of Information in Medicine, 58(4), 131-139. https:// doi.org/10.1055/s-0040-1701607

Hair, J., Black, W., Babin, B., \& Anderson, R. (2014). Multivariate data analysis (7th edn.). London: Pearson Education.

Harney, B., \& Dundon, T. (2006). Capturing complexity: Developing an integrated approach to analysing HRM in SMEs. Human Resource Management Journal, 16(1), 48-73. https://doi.org/10.1111/j.1748-8583.2006.00004.x

Hayes, A. (2017). Introduction to mediation, moderation, and conditional process analysis: A regression-based approach. New York, NY: Guilford Publications.

Herrero, I. (2017). Family involvement and sustainable family business: Analysing their effects on diversification strategies. Sustainability, 9(11), 1-20. https://doi. org/10.3390/su9112099

Hung, Y., Cant, M., \& Wiid, J. (2016). The importance of human resources management for small businesses in South Africa. Problems and Perspectives in Management 14(1-3), 232-238. https://doi.org/10.21511/ppm.14(3-1).2016.09

ILO. (2016). Policies, strategies and practices for the formalisation of micro and small enterprises. Geneva: International Labour Organisation.

Jaskiewicz, P., \& Dyer, W. (2017). Addressing the elephant in the room: Disentangling family heterogeneity to advance family business research. Family Business Review, 30(2), 111-118. https://doi.org/10.1177/0894486517700469

Jiménez, A., Palmero-Cámara, C., \& González-Santos, M.J. (2015). The impact of educational levels on formal and informal entrepreneurship. Business Research Quarterly, 18(3), 204-212. https://doi.org/10.1016/j.brq.2015.02.002

Karadag, H. (2017). The impact of industry, firm age and education level on financial management performance in small and medium-sized enterprises (SMEs): Evidence from Turkey. Journal of Entrepreneurship in Emerging Economies, 9(3), 300-314. https://doi.org/10.1108/JEEE-09-2016-0037

Kashi, K., \& Zheng, C. (2013). Extending technology acceptance model to the e-recruitment context in Iran. Journal of Selection and Assessment, 21(1), 121-129. https://doi.org/10.1111/ijsa.12022

Kelloway, E.K. (2015). Using Mplus for structural equation modelling: A researcher's guide (2nd ed.). New Jersey: Sage.

Li, S., \& Rees, C. (2020). Determinants of the formalization of human management practices: An empirical study in SMEs in eastern and western China. Journal of Small Business Management, 19(2), 1-21.

Li, S., \& Rees, C. (2020). Determinants of the formalisation of human management practices: An empirical study in SMEs in eastern and western China. Journal of Small Business Management, 1-21. https://doi.org/10.1080/00472778.2019.1705663

Lobonțiu, G., \& Lobonțiu, M. (2014). The owner-manager and the functional management of a small firm. Procedia - Social and Behavioural Sciences, 124, 552-561. https://doi.org/10.1016/j.sbspro.2014.02.519

Maduku, D.K. (2015). Determinants of mobile marketing adoption among SMEs in South Africa. PhD thesis. Johannesburg: University of Johannesburg.

Maichum, K., Parichatnon, S., \& Peng, K. (2016). Application of the extended theory of planned behaviour model to investigate purchase intention of green products among Thai consumers. Sustainability, 8(10), 1-20. https://doi.org/10.3390/ su8101077 
Mohd Nor, L. (2010). Decision making process: A comparison between family business and non-family business in the construction industry, the Bayesian causal map. Retrieved from www.researchgate.net/publication/268256052/

National Small Business Amendment Act (No. 29 of 2004). (2004). Pretoria: Government Printers.

Nzonzo, J., \& Matashu, M. (2014). An insight into the human resource management practices adopted by entrepreneurs in South Africa. Journal of Small Business and Entrepreneurship Development, 2(3), 73-87. https://doi.org/10.15640/jsbed. v2n3-4a5

OECD. (2017). Enhancing the contributions of SMEs in a global and digitalised economy. Paris: Organisation for Economic Co-operation and Development.

Ogubazghi, S., \& Muturi, W. (2014). The effect of age and educational level of owner/ managers on SMMEs' access to bank loan in Eritrea: Evidence from Asmara City. American Journal of Industrial and Business
https://doi.org/10.4236/ajibm.2014.411069

Poza, E.J., \& Daugherty, M.S. (2013). Family-owned business enterprises. Washington: South-Western Cengage Learning.

Psychogios, A., Szamosi, L., Prouska, R., \& Brewster, C. (2016). A three-fold framework for understanding HRM practices in South-Eastern European SMEs. Employee Relations, 38(3), 310-331. https://doi.org/10.1108/ER-07-2014-0078

PWC. (2018). Europe monitor - Innovation and digital transformation: How do European SMEs perform?. London: PricewaterhouseCoopers B.V.

Radipere, S., \& Dhliwayo, S. (2014). The role of gender and education on small business performance in the South African small enterprise sector. Mediterranean Journal of Social Sciences, 5(9), 104-110.

Riddell, W.C., \& Song, X. (2017). The role of education in technology use and adoption: Evidence from the Canadian workplace and employee survey. Industrial \& Labour Relations Review, 7O(5), 1219-1253. https://doi.org/10.1177/0019793916687719

Rogers, E.M. (2003). Diffusion of innovations. New York, NY: Free Press.

Rogerson, C. (2005). Unpacking tourism SMMEs in South Africa: Structure, support needs and policy response. Development Southern Africa, 22(5), 623-642. https://doi.org/10.1080/03768350500364224

Sideridis, G., Simos, P., Papanicolaou, A., \& Fletcher, J. (2014). Using structura equation modelling to assess functional connectivity in the brain: Power and sample size. Educational Psychological Measurement, 74(5), 733-758. https:// doi.org/10.1177/0013164414525397
Singh, M., \& Vohra, N. (2009). Level of formalisation of human resource management in small and medium sized enterprises in India. Journal of Entrepreneurship, 18(1), 95-116. https://doi.org/10.1177/097135570801 800105

Steenkamp, F., \& Bhorat, H. (2016). The role of skills and education in predicting microenterprise performance. Johannesburg: Labour Market Intelligence Partnership (LMIP).

Steijvers, T., Lybaert, N., \& Dekker, J. (2017). Formal human resource practices in family firms. Journal of Family Business Management, 7(2), 151-165. https://doi. org/10.1108/JFBM-07-2016-0016

Statistics South Africa. (2018). Discussion document on South Africa's accommodation industry. Johannesburg: Statistics South Africa.

Strydom, A., Mangope, D., \& Henama, U. (2019). Making community-based tourism sustainable: Evidence from the Free State Province, South Africa. GeoJournal of Tourism and Geosites, 24(1), 7-18.

Svendsen, G., Johnsen, J., Almås-Sørensen, L., \& Vitters $\varnothing$, J. (2013). Personality and technology acceptance: The influence of personality factors on the core constructs of the technology acceptance model. Behaviour \& Information Technology, 34(2), 323-334. https://doi.org/10.1080/014492 9X.2011.553740

Venkatesh, V., Morris, M.G., Davis, G.B., \& Davis, F.D. (2003). User acceptance of information technology: Toward a unified view. MIS Quarterly, 27(3), 425-478. https://doi.org/10.2307/30036540

Wilkerson, J.M., Seers, A., \& Johnson, S.G. (2020). On Antecedents of Functional Elaboration of HRM in Small Firms. Journal of Organizational Psychology, 20(1), 23-36.

Williamson, O. (2017). The transaction cost economics project: The theory and practice of the governance of contractual relations. New York, NY: E.E. Publications.

World Bank. (2018). South Africa economic update: Jobs and inequality. Washington, DC: World Bank.

Woldie, A., Leighton, P., \& Adesua, A. (2008). Factors affecting small and medium enterprises (SMEs): An exploratory study of owner-manager and firm characteristics. Bank and Bank Systems, 3(3), 5-13.

Yoshino, N., \& Taghizadeh-Hesary, F. (2018). The role of SMEs in Asia and their difficulties in accessing finance. Tokyo: Asian Development Bank Institute. 